\title{
'CONTAGION' (2011): The Portrayal of Society during COVID-19 Pandemic
}

\author{
Fatma Imalia Arifa*, Sukarjo Waluyo². \\ ${ }^{1}$ Master of Literature, Diponegoro University, Semarang, Indonesia \\ ${ }^{2}$ Master of Literature, Diponegoro University, Semarang, Indonesia
}

\begin{abstract}
Contagion (2011) was actually released in 2011 by Warner Bros, but since the COVID-19 pandemic broke out, this film has been on the rise again. This film shows the spread of a virus, as well as the government's efforts to deal with the spread of a virus that is rapidly spreading. This study aims to analyze the social issue inside the Contagion (2011) as well as in the society. This study uses descriptive qualitative research methods with data acquisition through surveys and observations and supported by literature studies related to the research theme along with sociology of literature as the supporting approach. The result of this research stated that the social issues is caused by the rumours and misleading information which leads to fear and panic among the society.
\end{abstract}

\section{Introduction}

It has been more than a year, people worldwide have been living with the endless pandemic so that they live under the fear of the COVID-19 pandemic. According to World Health Organization (2020), the virus of COVID-19 was first identified on January 7th 2020, but the case of COVID-19 transmission got higher in a short period. In less than a month, on January 29th 2020, there were 6,065 confirmed cases of COVID-19 all around the world, and 132 deaths were reported due to COVID-19 outbreaks. According to Ines (2020), the transmission of the COVID-19 virus was getting worse; 30 days later, on February 30th 2020, the confirmed COVID-19 cases reached 83,652 from 51 countries throughout the world. Unfortunately, the transmission of the COVID-19 pandemic is still happening now. The massive spread of the COVID-19 pandemic worldwide turned the world in fear to deal with it. The chaotic situation of the world was inevitable.

During the initial lockdown in early 2020, in order to reduce the rate of COVID-19 transmission, Kritz (2020) reported that the film entitled Contagion (2011) has been on the rise. It became No. 10 most rented or bought on iTunes. It also became more famous in the Google search engine in early 2020. This film was begun with the death of a businesswoman, namely Beth Emhoff, not long after her return from China. Soon after her death, her son also died on the same day with the same symptoms.

Meanwhile, her husband named Mitch, was fine at that time. The death of Beth was the beginning of the deadly infection of the virus in Hong Kong. Unfortunately, the doctors and

*Corresponding author: fatmaimalia067@gmail.com 
the researchers were not aware of the virus infection. Even the Centre for Disease Control needed several days to identify the virus and find a cure. While the government, through the $\mathrm{CDC}$, was busy finding a way to cure the sick, the virus was rapidly spread worldwide, and society started to crumble due to fear and panic. Nevertheless, Contagion (2011) was released long ago before the COVID-19 pandemic started to break out, but the film's scenario more or less depicted the social issues that appeared in the society. This article presents various life crises that emerged in film and reality related to social fear and anxiety since the COVID-19 pandemic began to spread.

\section{Methodology}

Research methodology is a way to solve the problem of the research scientifically and systematically. It also shows the researchers know the method and techniques is relevant to the research. This research uses the qualitative method through library research since the research data are in the form of words, phrases, sentences, paragraphs, and images. The research data were collected from observation through the film, both on intrinsic and extrinsic elements of the film related to the topic. The other data will be collected from the phenomena that happened during the COVID-19 pandemic in the news, articles or journals related to the topic.

This research will describe the intrinsic elements in the text along with the outside elements of a text. This research begins with an analysis of the Contagion (2011) and the life crises that occurred while the COVID-19 pandemic transmitted through almost the whole world. This research analyzes intrinsic elements in the form of figures, conflicts, place settings and phenomena in the film and our society in general, which are related to the topic and is supported by psycho-sociology. This research will use data from Contagion (2011), which deals with aspects of virus spreads, life crises, images of the world while the COVID-19 transmitted.

\section{Contagion (2011) and Social Issues}

\subsection{Contagion (2011)}

Contagion (2011) is a thriller movie released in 2011 that showed the deadly virus easily transmitted to people worldwide. This film is directed by Steven Soderbergh, an Oscarwinning filmmaker, and starred by some Academic Awards winners such as Matt Damon, Gwyneth Paltrow, Kate Winslet, Marion Cotillard and nominees Jude Law and Laurence Fishburne. This film shows the global citizens and governments faced various global crises due to the deadly outbreak of a fatal disease. The medical personnel were forced to find a cure to control and stop the fast pandemic growth. The massive spread of the deadly virus leads to death, panic, and fear worldwide.

Contagion (2011) tells us about the start of the unknown virus, which causes the sudden death of Beth Emhoff after returning from Hongkong. Not long after her death, her son also died with the same symptoms. Meanwhile, her husband, Mitch, is quarantined and examined by the medical team. World Health Organization sent an epidemiologist, Dr Leonora, to Hongkong to investigate where the virus came from and trace people who had contact with Beth there. Meanwhile, the Centers for Disease Control and Prevention (CDC) sent Dr Erin Mears to trace the people who had recently contacted Beth in Minneapolis. 
The CDC determined the virus and the origin then tried to formulate the antivirus or the vaccines.

The virus' contagion was getting worse; the death number increased, and so did the fear and panic in society. A journalist blogger named Alan Krumwiede spread a rumour that he cured himself with forsythia. That rumour caused panic buying, widespread looting and violence. Besides that, the lockdown was applied, so the people were not allowed to go out from the infected countries. Long story short, the CDC successfully formulated the antivirus and got permission from the government to mass-produce the vaccines, then distributed to the citizens. Then, the life of the people started to return to normal.

\subsection{Virus}

According According to Shereen et al. (2020), the novel coronavirus originated from the Hunan seafood market in Wuhan, China, where bats, snakes, raccoons, dogs, civets and other animals are sold. Even though the zoonotic source of the COVID-19 is not confirmed, the researchers suggested bats as the vital reservoir. Meanwhile, in Contagion (2011), the virus named MEV-1 originated from Macau. From the film's epilogue, the virus came from a banana which the bat ate, but the banana fell into a pigsty, and the pigs ate it. Later on, the contaminated pigs were processed by the chef in a restaurant. The first contamination to humans happened when the chef met Beth while he was cleaning a pig; the virus came from the mouth of the contaminated pig. The first contamination happened because the chef did not wash the hand before he met Beth, then he did a handshake with Beth there, then it spread all over the casino where Beth hung out.

The virus of COVID-19 and the MEV-1 in the film had similar place origin. They came from China, Wuhan and Macau. They also had the same reservoir; the scientists believed that bats were the COVID-19 key reservoir, and so did the MEV-1 caused by the bats and delivered through pork. As we can see in the film, the contagious process through contact with the virus-host meanwhile. It is somewhat different to the COVID-19; WHO (2020) stated that the COVID-19 spreads from the infected person's droplets or even smaller aerosols when they cough, sneeze, speak, sing or breath. People also can be infected by touching the surface that has been touched by the host when they touch their face without cleansing their hands.

The infected people were not directly sick, but they needed some time to show the symptoms. Each virus has different symptoms and incubation period. Gennaro et al. (2020) analyzed that the main COVID-19 associated symptoms are fever, cough, headache, sore throat, and loss of smell. In the worst scenario, the infected people can experience difficulty breathing, which can lead to death later on. Then, Dhouib et al. (2021) stated that the incubation period of the COVID-19 is eight days to twelve days, respectively. However, through that research they conducted, it is also possible that the incubation period can be up to fourteen days according to the people's condition. Different from COVID-19, the MEV1 in that film the virus only needed four days to kill Beth Emhoff with cough, acute fever, and convulsions as the symptoms. The other symptoms experienced by the other victims, Dr Mears, are severe headaches, difficulty breathing, and cold.

\subsection{Social Issues}

\subsubsection{Fear}

The spread of the COVID-19 inevitably triggered social fear among the society since its rapid and massive spread all over the world. According to World Health Organization, on March 11th 2020, COVID-19 has increased 13 times outside China. There were more than 118.000 cases in more than a hundred countries, and 4.291 people died; meanwhile, more than thousands were fighting for their lives. The daily new cases and death were also 
getting higher by the end of March, the confirmed new cases surpassed 509.164, and the death surpassed 23.335 people. Patel et al. (2020) stated that people's responses to the terror of the infectious virus could lead society to fear, stress, anxiety and insecurities, especially with the sudden and rapid spread rate and the high death rate.

Contagious (2011) also shows how Mitch protected Jory, his daughter, from meeting her boyfriend and asked his daughter's boyfriend to stay away from Jory and bring back the flower. Scene (59:25) also reflected the insecurities of Mitch while he and Jory were in the supermarket to buy their daily needs. That scene showed a woman who had a severe cough and asked for help, but Mitch chose to ignore the woman then asked Jory to take off her gloves and spray the sanitiser all over her hand. It represented how people tried to avoid the contagious virus in order to survive in that situation. As we have found COVID-19 in China, it is inevitable that social stigma and discriminatory behaviours against people of China backgrounds and anyone who have been in contact with the virus started to begin. It can be reflected in how people banned Chinese from visiting other countries like The Royal Caribbean, which banned all Chinese nationals from its cruise ship as reported by theguardian.com in February 2020.

In other cases, as we remembered on antaranews.com in March 2020, Indonesians rejected the COVID-19 patients and the COVID-19 victims' corpses. In East Jakarta, a nurse who treated COVID-19 patients was not welcomed into her neighbourhood because her neighbour feared that she would spread the virus; in worse cases, some nurses were evicted from their rented house for similar reasons April 2020. There were cases of people rejecting the corpses of COVID-19 in some regions of Indonesia in around mid-2020.

\subsubsection{Panic}

Not Not only fear, but people also experienced panic since the fatality of the COVID-19 getting higher day by day. Niconmendes, CJC (2020) stated that global pandemics bring various reactions from people depending on their cultural orientation. Moreover, the mass and social media also contributed to public panic since the possibility of misinformation and excessive information led to egoism in the form of panic buying and xenophobia. During this pandemic, one of the most unique phenomena is the scarcity of medical masks and hand sanitisers throughout the world. At first, BBC News, on June 6th 2020, reported that WHO only advised to do social distancing and wear masks; it also stated that the medical masks should be worn by people who are sick and by the medical personnel. Hence, the world's people are already overwhelmed about the COVID-19 outbreaks; people already bought the medical masks long before the WHO released the advice.

People bought medical masks in a large amount for their family and themselves to avoid the infection of the COVID19. The overwhelmed condition leads to the shortage of masks all over the world. Bruno (2020) in usnews.com captured a note reading in Italian, which means 'masks sold out' hung on the window in pharmacy in late February 2020.

Gunia (2020), through Time, also stated that pharmacies in Germany, Canada, Italy, and the U.K were experienced the medical masks supply. The high demand for medical masks and the low production process made the medical masks' price grow higher and higher. She also stated that online retailers surged to hundreds of dollars. Meanwhile, Katie Forster (2020), a journalist of Agence France-Presse, tweeted in her Twitter account and stated that in a central London pharmacy was charged $£ 2.50$ for surgical masks. There are no other pharmacies that still had stocks.

The panic over COVID-19 transmissions caused the shortage of medical or surgical masks and hand sanitiser. Suthivarakom (2020), through New York Times, stated that sanitisers from Purell and other brands were exceedingly running out of stocks. If the pharmacies or the sellers still had stocks left, they would charge it to outrageously inflated 
prices. This condition was inevitable during this pandemic because hand sanitisers were the easy way to clean the germs when out to the public area.

\subsubsection{Rumors}

Different Unlike the shortage of masks and hand sanitiser worldwide, the Contagion (2011) showed the panic of the people throughout the United States when the citizens were informed by a journalist blogger named Alan Krumwide that he had cured himself using forsythia. Because of the rumour she spread, dozens of people queued up to get it. Unfortunately, the scenario of the shortage of the forsythia is worse than the shortage of masks and hand sanitisers. The shortage of forsythia leads the citizens to do widespread loot and violence. They destroyed pharmacies and even burned them down.

That chaotic situation was caused by an independent journalist and blogger, Alam Krumwide, who did not believe in the MEV-1 and insisted it was a biological weapon resulting from a conspiracy between Centre Disease Control and the pharmaceutical industry. He believed that the government was behind this since they declined to perform an autopsy on a Japanese man who fell on the bus. He started to spread his belief toward society; he created rumours that he was infected by the MEV-1 and treated himself with forsythia. Those kinds of rumours were not only appeared in the film but also the reality. Nowadays, looking for information is just a piece of cake since advanced technology, and the massive source of information forms both mass and social media. Patel et al. (2020) stated that the flow of information is much faster than the virus, especially from social media. Yet, the information from social media is uncontrollable and lacks credibility, so it leads to confusion, panic, anxiety among society. According to Abdoli (2020), there were so many rumours about the virus and the cure, which led to social confusion such as; COVID-19 was transmitted through 5G networks which led to destruction toward some $5 \mathrm{G}$ towers in some countries in South America, and consuming particular food (e.g., garlic, onion, ginger, spices) can cure the COVID-19.

\section{Conclusion}

Through Contagion (2011), people can see the worst scenario when the deadly virus spreads worldwide. It can be a precaution for people all over the world to understand the situations they are in. Moreover, the social issues are caused by rumours and misleading information, which leads to panic and fear. Both people must obtain and share information from credible and reliable sources to avoid confusion, fear, panic, and hoaxes. The government must provide reliable information and fight against rumours and hoaxes.

\section{References}

1. Abdoli, A. Gossip, Rumors, and the COVID-19 Crisis. Disaster medicine and public health preparedness vol. 14,4 (2020): e29-e30. doi:10.1017/dmp.2020.272

2. Dhouid, et al. The incubation period during the pandemic of COVID-19: a systematic review and meta-analysis. SR. 2021

3. Evelyn, K. Coronavirus: Royal Caribbean bans all Chinese nationals from its cruise ships. The Guardian. Feb, $7^{\text {th }}$ 2020. Retrieved from https://www.theguardian.com/

4. Firdaus, A. Penolakan terhadap tenaga medis COVID-19 terjadi sejak Minggu. Antara News. March, 25 ${ }^{\text {th }}$ 2020. Retrived from https://www.antaranews.com/

5. Future Perspectives: A Narrative Review. IJERPH. 2020

6. Gennaro, et al. Coronavirus Diseases (COVID-19) Current Status and 
7. Gunia, A. There Aren't Enough Medical Masks to Fight Coronavirus. Here's Why It's Not Going to Get Better Anytime Soon. Time. February $27^{\text {th }} 2020$.

8. Ines, S. A hundred days into the coronavirus disease (COVID-19) pandemic. ES. 2020

9. Kritz, F. Fact-Checking 'Contagion' - In Wake Of Coronavirus, The 2011 Movie Is Trending. NPR. Retrieved February 16, 2020, from https://www.npr.org/.

10. Nicomedes, CJC, and Avila, RMA. An analysis on the panic during COVID-19 pandemic through an online form. Journal of affective disorders vol. 276 (2020): 1422. doi:10.1016/j.jad.2020.06.046

11. Patel, Mohan P, et al. "Infodemic" COVID 19: More Pandemic than the Virus. Indian journal of nephrology vol. 30,3 (2020): 188-191. doi:10.4103/ijn.IJN_216_20

12. Sheeren, et al. COVID-19 infection: Origin, transmission, and characteristics of human coronaviruses. JAR. 2020

13. Suthivarakom, G. Coronavirus Has Caused a Hand Sanitizer Shortage. What Should You Do? NYTimes. March $21^{\text {st }} 2020$.

14. UnBBC. Coronavirus: WHO advises to wear masks in public areas. BBC. June $6^{\text {th }}$ 2020. Retrieved from https://www.bbc.com/

15. World Health Organization. Coronavirus disease 2019 (COVID-19): Situation Report - 67. 2020. Retrieved from https://www.who.int/

16. -. Mask use in the context of COVID-19. 2020. Retrieved from https://www.who.int/

17. -. WHO Director-General's opening remarks at the media briefing on COVID-19. 2020. Retrieved from https://www.who.int/ 